\title{
Dealing with deontic modality in a termbase: the case of Dutch and Spanish legal language
}

\section{Patricia Vanden Bulcke}

Ghent University, Belgium

Patricia.VandenBulcke@UGent.be

In this article, we analyse, on the basis of comparable corpora (DutchSpanish) of the same legal genre, that is, the Articles of Association, an aspect of cross-linguistic variation, namely the expression of deontic modality. We also examine the ways in which the findings of the study can be processed into a bilingual, translator-friendly legal termbase (JuriGenT). In doing so, we map out the asymmetry, which is mainly attributable to the use of tenses, and duly process this in the relevant term records, taking the view that the translator should be aware of the similarities and differences of their usage so as to be able to make wellconsidered translation decisions.

\section{Introduction}

In this article, we seek to demonstrate the way corpus-driven terminography based on comparable corpora inevitably encompasses critical discourse analysis. Our research concentrates on JuriGenT, a bilingual Dutch-Spanish database of legal terminology related to one specific legal genre, namely the Articles of Association.

With the help of these comparable corpora, we examine the crosslinguistic variation of the studied genre in terms of use of tenses and modal verbs when expressing deontic concepts. Moreover, we demonstrate how this information is included in the term records of JuriGenT. This article does not claim to be a theoretical contribution to contrastive research of the legal discourse, but rather a pragmatic, smallscale, corpus-based study which hopes to offer legal translators insights into the way in which Dutch and Spanish handle deontic modality.

\section{JuriGenT, premises and consequences}

The termbase JuriGenT (which stands for Juridische Terminografie aan Universiteit Gent - Legal Terminography at Ghent University), is based on six premises (see also Vanden Bulcke \& De Groote, 2011). It is: 
- corpus-driven, on the basis of a comparable, Dutch and Spanish corpus;

- $\quad$ specialised, containing legal terminology from the Articles of Association (corporate law);

- $\quad$ systemic, Belgian and Spanish legislation;

- $\quad$ usable for translations into and out of the languages concerned;

- $\quad$ with access to the entries, both alphabetical and via tree structures;

- $\quad$ with a specific target audience in mind (Cabré et al., 2003; Cabré Castellví, 2005; Temmerman, 2000, p. 235), namely translators, rather than lawyers. JuriGenT currently comprises 1,150 concepts, which, it is estimated, add up to at least 4,600 terms (or units, see below). Both the Dutch and Spanish corpora contain 400,000 words each $(200,000$ basic corpus $+200,000$ control corpus).

Premise 6, that is, the decision to tailor the termbase to the specific target audience of translators has a few implications that merit some explanation. Cognitive linguistics assumes that concepts are embedded in wider knowledge structures and that "linguistic units serve as prompts for an array of conceptual operations and the recruitment of background knowledge" (Evans, 2006, p. 160). Legal terms and related concepts will inevitably trigger domains among translators that are different from those among lawyers: "Since meaning is a mental process, it invites idiosyncrasy: the domains activated among conceptualizers will differ depending on their experience and knowledge" (Biel, 2009, pp. 2-3). This results in a specific selection and handling of units included.

In terms of selection, we opted for three types of units: terminological units, units that combine legal paradigms, and phraseological units (Vanden Bulcke \& De Groote, 2011). As the latter move a step closer to discourse analysis, the database dovetails with the new socio-cognitive terminological trend (Stubbs, 2004; Temmerman, 2000; Teubert, 2002), which, in addition to terms and fixed compound words, also takes cognitively justified patterns and their specific linguistic expressions into consideration. We would, in this connection, refer to the collocations included in Section 3.1.4.

In terms of managing the selected items, we decided, probably rather controversially given the system interdependence of the terminology, to start the term records with overarching definitions (or 'concept descriptions', in Dutch) that are independent of the Spanish and Belgian legal frameworks and to list, again in the first part of the record, all the Dutch and Spanish equivalents for the concept, indicating in specific fields any concept-related discrepancies between them.

The intended objective of the termbase should, however, come with a caveat: the termbase only offers tentative translation solutions, which the translator can accept on the basis of context. As compilers of the database, we do not adopt a firm position with regard to a foreignising or domesticating translation strategy (Biel, 2009; Mayoral Asensio, 
2003; Nord, 1997; Šarčević, 2000; Vanden Bulcke \& Héroguel, 2011) and, consequently with regard to the concomitant translation techniques, which range from transcription to functional equivalent (Alcaraz \& Hughes, 2002; Biel, 2009, 2010; Borja Albi, 2007; Vanden Bulcke \& Héroguel, 2011).

This was done on purpose, for, as is evident from the quote below, no consensus has as yet been reached on the role of legal and/or sworn translators when it comes to discrepancies with regard to the legal systems. The question is: how should the translator deal with these? Should these discrepancies be adapted, clarified or retained?

Generally, although translators are expected to fill in the knowledge gaps of the target audience, this issue raises some controversy in legal translation. The influential Polish Sworn Translator Code claims that translators are entitled to assume that the recipient is aware of incongruities within the legal systems; hence, translators do not have to provide any additional explanations or definitions (Kierzkowska 2005: 87-88). On the other hand, in TL-oriented approaches, such as Šarčević's receiveroriented approach, it is argued that translators should "compensate for conceptual incongruity whenever possible" to ensure that SL text and the translation have the same legal effect. (Biel, 2009, p. 6)

The above question coincides with the question to what extent a translator can interpret a legal source text. Šarčević (2000) refers to the 'emancipation' of legal translators since the 80s who "are now widely permitted to make legal as well as linguistic decisions" (p. 112). Accordingly, the pursuit of a 'uniform intent' has become crucial in determining the acceptability of a translation: "The translator's first consideration is no longer fidelity to the source text but rather fidelity to the uniform intent of the single instrument, i.e. what the legislator or negotiators intended to say" (Šarčević, 2000, p. 112). It is clear, however, that in certain cases, even the source text does not permit uniform interpretation, and the final interpretation should be left to a judge (Šarčević, 2000, p. 138). We set out our position on this issue in Section 3.1.3.

\section{Cross-linguistic variation in the same text genre}

Legal texts can, according to the typology of Borja Albi and Hurtado Albir (1999, pp. 154-156), be divided into several major categories, which include text genres that may vary from country to country. Articles of Association fall within the category 'applications of the law'. In Belgium and Spain, the genre is quite symmetrical in form and content, as 
it contains a company's ground rules and rules of operation, laid down in the deed of incorporation and divided into chapters and articles.

Every translator intuitively knows that a legal text is more than a string of legal words. Both Alcaraz and Hughes (2002, pp. 101-102) and Gémar (2002, p. 165) mention terminology, form and style as features of a 'text genre'. For the legal genre, Gémar (2002, p. 165) adds the 'normative character', something that the present study builds on unreservedly. Modal verbs and tenses have been selected as parameters in the research into that modality. Even though tenses are grammatical markers (Palmer, 2001, p. 9), both Croft (1995, p. 88) and Šarčević (2000, p. 137) note that grammatical parameters alone are not sufficient to describe the variation in modality between the different languages, as indeed, they go hand in hand with external parameters, such as semantics, pragmatics and discourse.

\subsection{Expression of deontic modality}

Jurisprudence draws a distinction between constitutive and regulatory standards (Hildebrandt \& Gaakeer, 2005, pp. 9-10). The former define new concepts or create new institutions and are, in theory, not deontic, while the latter regulate human behaviour and human relations, and express a deontic concept (Deschamps, 2010, p. 166). The text genre of the Articles of Association contains, primarily, regulatory standards: they determine what must, can, may and may not be done, and define the parties involved. The deontic modality is central to the studied text genre. Since every language has its own lexical and grammatical ways of expressing this modality, it is imperative for translators to use the correct equivalents in each language. Below are the findings on the topic in the literature, which we have verified against our corpora of Articles of Association.

\subsubsection{Description on the basis of the Belgian Dutch corpus}

Deschamps (2010), an authority in the Dutch-speaking world in this field, has described deontic modality in Dutch regulatory documents based on corpus-based research. She claims (2010, p. 167) that Dutch has 66 different linguistic tools at its disposal to express deontic modality, that is, command, permission, authority (competence) and entitlement. For the purposes of this article, we confine ourselves to those tools that are inconsistent with the Spanish language: these are not the deontic adjectives + verb, such as belast zijn met [be entrusted with], onderworpen zijn aan [be subject to], bevoegd zijn voor [be authorised], mogelijk zijn [be possible], stemgerechtigd zijn [be entitled to vote], uitvoerbaar zijn [be feasible ]... or, indeed, the deontic nouns + verb, 
such as ten laste komen van [be borne by], de bevoegdheid hebben [have the authority], de bevoegdheid uitoefenen [exercise the authority], het recht hebben [be entitled]..., for these have lexical equivalents in Spanish, which are, in fact, listed in the termbase. Instead, they are: (a) the imperative verbs dienen te [roughly equivalent to 'to be to'] and zullen [shall], (b) the modal verbs kunnen [can, could] and mogen [can, may], which mainly express an authority, and (c) the modal verb moeten [must, have to, be obliged to] and the indicative present, which express both a command (see the 'normative indicative' of Šarčević, 2000, p. 140) and an authority. We would, in this connection, refer to the semasiological analysis of Deschamps (2010, p. 169) and the relevant classification. In the paragraphs below, we will examine how these items appear in the corpus.

The imperative verb dienen te [must, need, should, ought to] appears 159 times in our corpus. A random sample demonstrates, as illustrated in ex.1, that the verb invariably expresses a command, as confirmed in Deschamps's corpus (2010, p. 169, p. 174).

(1) De oproeping dient de te behandelen onderwerpen te bevatten, alsmede de voorstellen tot besluit. (Articles of Association AgfaGevaert)

The notice must contain the items to be discussed and the proposals for decision. (Articles of Association Agfa-Gevaert)

The verb zullen [shall] — the future tense - appears in Deschamps's corpus $(2010$, p. 174) with a deontic denotation just once, namely to express a command, which shows that this is not the standard means of expressing a command. Even though we noticed a more frequent use of the future tense (569 hits) in the Dutch corpus of Articles of Association, purely temporal denotations should be discounted in this connection. Moreover, separating the deontic denotations (ex. 3) from the temporal ones (ex. 2) is more easily said than done. For example, example 2 refers to the future, but also implies a command. Even though an exhaustive qualitative analysis strikes us as imperative, the hypothesis is, in accordance with Deschamps's findings, that the future tense with deontic meaning occurs less frequently than the present with deontic meaning.

(2) Aan de raad van bestuur is bij besluit van de algemene vergadering de dato negen mei tweeduizend en drie de bevoegdheid verleend, om binnen de termijn van vijf jaar te rekenen van de datum van de bekendmaking van het besluit [...] tegen de voorwaarden die de raad zal bepalen, het kapitaal te verhogen met een maximum bedrag van acht miljoen Euro. (Articles of Association Belgische Scheepvaartmaatschappij)

By decision of the General Meeting dated 9 May Two Thousand and Three, the board of directors has been granted the authority to 
increase the capital by a maximum amount of EUR eight million within a period of five years from the date of publication of the decision [...] in accordance with conditions that shall be determined by the board. (Articles of Association Belgische Scheepvaartmaatschappij)

(3) Geen enkele overdracht van aandelen op naam zal worden ingeschreven in het aandeelhoudersregister van de vennootschap gedurende de vier dagen die deze van de algemene vergadering voorafgaan, inclusief de dag van de algemene vergadering. (Articles of Association Belgische Scheepvaartmaatschappij)

No transfer of nominative shares shall be registered in the share register of the company for four days that precede the general meeting, including the day of the general meeting. (Articles of Association Belgische Scheepvaartmaatschappij)

The second category contains the modal verbs kunnen [can, could] (1455 hits) and mogen [can, may, should, ought to] (573 hits). Even though Deschamps (2010, p. 169 , p. 174) classifies these verbs mainly as verbs expressing authority, she does admit that they can also have other meanings, and that extra-linguistic information is required to determine these meanings. A spot check teaches us that kunnen in Articles of Association mostly expresses authority accompanied by freedom (ex. 4) while mogen (ex. 5) mostly implies permission, which, according to Deschamps (2010, p. 173) are, in fact, the recommended meanings of both verbs.

(4) Iedere aandeelhouder kan per brief, telegram, telex, telefax of op een andere schriftelijke wijze een volmacht geven om hem op de algemene vergadering te vertegenwoordigen. (Articles of Association Arinso International)

Each shareholder can grant a mandate to another party by letter, telegram, telex, fax or in any other written means to represent him/her at the general meeting. (Articles of Association Arinso International)

(5) Ieder eigenaar van een aandeel mag zich op de algemene vergadering door een speciaal gevolmachtigde doen vertegenwoordigen mits deze zelf aandeelhouder is. (Articles of Association Belgische Scheepvaartmaatschappij)

Each owner of a share may have him/her represented at the general meeting by an authorised representative, provided the latter is also a shareholder. (Articles of Association Belgische Scheepvaartmaatschappij) 
The last group contains moeten [must, have to, be obliged to] and the indicative present, which according to Deschamps (2010, p. 169) have an ambivalent meaning in regulatory documents: command and/or authority. Moeten has 571 hits in our corpus. A spot check tells us that the meaning is mainly that of obligation, although further research will have to confirm this.

(6) Binnen dezelfde termijn moeten de houders van aandelen op naam of hun vertegenwoordigers kennis geven van hun voornemen om aan de vergadering deel te nemen bij een gewone brief, te richten aan de zetel van de vennootschap. (Articles of Association Home Invest Belgium)

Within the same period, the holders of nominative shares, or their representatives, $\underline{\text { must }}$ give notice of their intention to attend the meeting by regular letter, to be addressed to the registered office of the company. (Articles of Association Home Invest Belgium)

For the use of the present indicative, we refer to Deschamps and Smessaert (2011). In their corpus, that tense is very polysemous and expresses all deontic concepts, where command (41.8\%) and competence $(54.1 \%)$ are among the most commonly used (Deschamps \& Smessaert, 2011, p. 149). We cannot glean any numbers about the indicative present from our non-labelled corpus, but Articles of Association are mainly written in that tense, as is demonstrated in most quoted examples, and specifically in examples 7, 8 and 9 .

(7) Zij [De algemene vergadering] beslist of de vereffenaars, indien er meer zijn, alleen, gezamenlijk, dan wel als college de vennootschap vertegenwoordigen. (Articles of Association Barco) It [the General Assembly] decides whether the liquidators represent the company as a group, alone, jointly or as a board. (Articles of Association Barco)

(8) Zij [de vennootschap] doet alle financiële, commerciële of industriële verrichtingen die van aard zijn de verwezenlijking van haar doel te begunstigen [...]. (Articles of Association Belgische scheepvaartmaatschappij)

It [the company] performs all financial, commercial or industrial operations which are likely to promote the achievement of its goal. (Articles of Association Belgische scheepvaartmaatschappij)

(9) Het directiecomité bestaat uit ten minste twee leden, die al dan niet bestuurder zijn. (Articles of Association Barco)

The executive committee consists of at least two members, who may or may not be directors. (Articles of Association Barco) 
The correct interpretation of the deontic meaning of the indicative present is not always straightforward in English, nor in other European languages (Šarčević, 2000, p. 138), for that matter. While example 7 appears to express what 'ought to be done', example 9 expresses what 'ought to be' 'Ought to be' sentences can generally be rewritten into 'ought to do' sentences. Example 8, however, cannot be paraphrased using the modal verb moeten [ought to], as it contains a competence that can be either discretionary (free to be performed) or mandatory (obliged to be performed) (Šarčević, 2000, p. 145). As acknowledged by Deschamps (2010, pp. 169-170) and Deschamps and Smessaert (2011), it is generally "not possible to determine on purely linguistic grounds whether a competence-conferring norm sentence put in the present indicative is discretionary or mandatory" (p. 147) and it is even necessary to consult legal textbooks to determine the intention of the lawgiver.

The present indicative also expresses constitutive norms, but sentences like those can, according to Deschamps and Smessaert (2011, pp. 152-153), hardly be distinguished from the 'ought to be' sentences and can also be interpreted deontically.

\subsubsection{Description on the basis of the Spanish corpus}

For Spanish, corpus-driven research into the deontic modality in legal documents has been carried out by, inter alia Chierichetti (2001), López Samaniego (2006), López Samaniego and Taranilla (2012) and Taranilla (2010). Only Chierichetti (2001) is working on a regulatory corpus, as a result of which the findings of the other researchers only partly apply to Articles of Association. There is also a brief mention of the use of the futuro in Álvarez Calleja (2002, p. 36) and the reference below:

Para indicar mandato el discurso jurídico emplea las perífrasis de sentido obligativo, el futuro de mandato, el presente de indicativo y el imperativo. El que con mayor frecuencia se emplea es el futuro de mandato que aparece en segunda y tercera persona del singular y plural y expresa mandato o prohibición. (Ortega Arjonilla, Doblas Navarro, \& Paneque Arana, 1996, pp. 34-35)

To express a command, Spanish legal discourse uses the imperative periphrases, the normative future, the indicative present and the imperative. The normative future is most commonly used. It appears in the second and third person singular and plural and conveys a command or prohibition. (Ortega Arjonilla, Doblas Navarro, \& Paneque Arana, 1996, pp. 34-35)

The periphrases that express an obligation (must, have to, to be obliged to) are, according to the Real Academia Española (RAE) (1973, p. 447, p. 450) haber de, haber que, tener que, tener de and deber + infinitive. In 
the Nueva gramática de la lengua española (2009) (RAE \& AALE) deber + infinitive, the construction with the highest incidence in our corpus, is considered a modal verb with mainly radical meaning (vol. II, §28.6i), namely obligation, and haber de + infinitive, the second most prevalent construction, as a verb with radical and epistemic meaning (vol. II, §28.6ñ-\$28.6r), although the latter mainly occurs in literary use (vol. II, §28.6q) and is not applicable in the studied context. Of the five quoted verb groups, two are absent in our corpus, namely haber que and tener $d e$, which is also borne out by Chierichetti (2001, p. 252). For completeness' sake, the subjuntivo and condicional are included in the table below, but they are not discussed any further.

Table 1: Verbs with imperative meaning in the Spanish corpus: tenses and frequencies

\begin{tabular}{|l|l|l|l|l|}
\hline Verb & $\begin{array}{l}\text { Presente de } \\
\text { indicativo }\end{array}$ & $\begin{array}{l}\text { Futuro de } \\
\text { indicativo }\end{array}$ & $\begin{array}{l}\text { Presente/Imperfecto } \\
\text { de subjuntivo }\end{array}$ & Condicional \\
\hline $\begin{array}{l}\text { Deber (595) } \\
\text { Deber de (5) }\end{array}$ & $\begin{array}{l}29 \\
\text { Haber de } \\
(257)\end{array}$ & 63 & $\begin{array}{l}79 \\
1\end{array}$ & 1 \\
\hline Tener que (7) & 2 & 92 & 102 & 0 \\
\hline Haber que (0) & 0 & 4 & 1 & 0 \\
\hline Tener de $(0)$ & 0 & 0 & 0 & 0 \\
\hline
\end{tabular}

The three verbs that appear in our corpus are imperative in meaning: deber_is, as described in Chierichetti $(2001$, p. 252), by far the most frequently used verb, followed by haber de and tener que. The radical variant of deber de appears in our corpus 5 times. The infrequent use of tener que is also a remarkable phenomenon in Taranilla (2010, p. 254), and in Chierichetti (2001, p. 252) it does not occur at all. The following are examples:

(10) La inscripción de las acciones debe estar hecha a nombre de persona o personas determinadas que habrán de ser su propietario. (Articles of Association Banco de Galicia)

The registration of the shares must be done on behalf of specific persons who own them. (Articles of Association Banco de Galicia)

(11) Los copropietarios de una acción habrán de designar una sola persona para el ejercicio de los derechos de socio. (Articles of Association Amper) 
The joint owners of a share must designate a single person for exercising their rights as shareholder. (Articles of Association Amper)

(12) Los acuerdos se aprobarán por mayoría, salvo en el supuesto del número segundo del artículo 103 de esta disposición en el que tendrán que ser de dos tercios del capital presente o representado en la Junta. (Articles of Association Española del Zinc)

Decisions are taken by majority of votes, except in the case described in paragraph two of Article 103, where two thirds of the capital present or represented must be obtained at the general meeting. (Articles of Association Española del Zinc)

The second way of expressing deontic meaning is the futuro de indicativo, which is also the most prevalent way, according to the quoted excerpt and Chierichetti (2001, pp. 243-244). The Spanish corpus bears this out with 8872 hits. The second person singular and plural are, unlike what is claimed in the above quote, not used.

A random quality check of the Spanish corpus teaches us that it is not easy to distinguish the futuro with temporal meaning (see ex. 13) from the futuro with deontic meaning (ex. 14, ex. 15). Like in Dutch, a temporal futuro (ex. 13) can also be interpreted deontically. Moreover, it is not always clear whether the futuro implies a mandatory authority (obliged to be performed) (ex. 14) or indeed a discretionary (free to be performed) one (ex. 15).

(13) Si durante el plazo para el que fueron nombrados los miembros del Consejo se produjesen vacantes, la Junta General designará las personas que hayan de ocuparlas [...] por el periodo de tiempo que al sustituido le quedara por cumplir. (Articles of Association Ingra) If, during the period for which they were appointed, a vacancy were to present itself, the General Assembly shall designate the persons who fill the vacancy for the remainder of the mandate. (Articles of Association Ingra)

(14) Las discusiones y acuerdos del Consejo se llevarán a un libro de actas y cada acta será firmada por el Presidente y el Secretario o por quienes les hubiesen sustituido. (Articles of Association Acerinox)

The deliberations and decisions of the Board shall be recorded in a minute book, and all minutes shall be signed by the President and Secretary, or by their substitutes. (Articles of Association Acerinox) 
(15) La votación por escrito y sin sesión será admitida cuando ningún Consejero se oponga a este procedimiento. (Articles of Association Acciona)

Voting in writing without a meeting shall be permitted when no director objects to this procedure. (Articles of Association Acciona)

Table 1 demonstrates that Spanish often combines two language expressions for deontic modality: the lexical verbs deber, haber de, tener que and the futuro, as pointed out by Chierichetti (2001, p. 251). This seems to suggest that the imperative meaning of the futuro and/or the lexical verbs, is in itself insufficient or too ambiguous to express an obligation.

A third option is the presente de indicativo, which is used in the Spanish Articles of Association, but significantly less frequently than the futuro de indicativo. A case in point: decide( $n)$ [decides/decide] appears 4 times and decidirá(n) [will decide] 40 times. Similarly, nombra(n) [appoints/appoint] does not appear and nombrará(n) [will appoint] 25 times. The same for cesará(n) [will dismiss], 32 hits, compared to no hits for $\operatorname{ces} a(n)$ [dismisses/dismiss]. The difference in meaning is only minor (see ex. 16 and 17). The presente de indicativo can, alongside obligation, like in example 16, also express discretionary competence, as illustrated in example 18.

(16) La Junta General, debidamente convocada y válidamente constituida decide por mayoría de votos emitidos por los accionistas presentes o representados con derecho de voto, en los asuntos de su competencia [...]. (Articles of Association Azkoyen)

The regularly convened and duly constituted general meeting decides by majority of votes cast by the shareholders present or represented with voting rights, in matters within their competence. (Articles of Association Azkoyen)

(17) La Junta General de accionistas decidirá sobre todos los asuntos que, de acuerdo con la Ley y los estatutos, sean de su competencia [...] (Articles of Association CIE Automotive)

The general meeting of shareholders shall decide on the matters within their competence, in accordance with the law and this Articles of Association. (Articles of Association CIE Automotive)

(18) Constituye el objeto de la Compañía: a) La fabricación y venta de todos los productos químicos y sus derivados. b) [...] e) [...].

(Articles of Association Energía e Industrias Aragonesas) The object of the company $\underline{i s}$ to: a) manufacture and sell all chemicals and their derivatives. (b) ... e). (Articles of Association Energía e Industrias Aragonesas) 
Chierichetti (2001, pp. 246-249) postulates that the presente de indicativo is used more to express a constitutive standard, i.e. standards that define concepts or create institutions. This is also the case in our corpus, see son [are] in ex. 19. However, Chierichetti (2001, p. 248) underlines that the distinction with the futuro, the tense, par excellence, that expresses obligation, is difficult to draw: "Estos tipos de enunciados se hallan muy cerca de los deónticos, y no es difícil confundirlos" [Even though these types of statements are very close to the deontic ones, they are very hard to distinguish from one another. (My translation)].

Chierichetti (2001, p. 248) also brings up the contrastive use of both tenses: first a constitutive presente, followed by a deontic concretisation in the futuro. This use is a regular occurrence in our corpus, too, see ex. 19:

(19) Las acciones son indivisibles. Los copropietarios de una acción habrán de designar una sola persona para el ejercicio de los derechos de socio. (Articles of Association Amper)

The shares are indivisible. The joint owners of a share $\underline{\text { must }}$ designate one single person to exercise their rights as shareholders. (Articles of Association Amper)

The use of the Spanish presente is therefore ambiguous, even though, according to our spot checks, it scores significantly lower in the purely deontic meaning than the use of the deontic futuro.

Since the fourth possibility quoted, namely the imperativo, does not appear in our corpus, nor in that of Chierichetti (2001, p. 242), it is not included in the diagram. In fact, Šarčević (2000, p. 139) claims that the imperative is avoided in more than one legislation, because "it is considered too direct".

Finally, we would like to turn our attention to the non-imperative poder. Taranilla (2010, p. 257) claims that it grants 'permission' and is common in regulatory documents. López Samaniego (2006, p. 122) describes poder as a semi-modal verb that expresses possibility, as borne out in the RAE \& AALE (2009, vol. II, §28.6w). Furthermore, we notice the same phenomenon with poder as we do with deber, haber de and tener que: namely that the verb is mainly used in the futuro, probably to add more force to the permission (ex. 20) or possibility (ex. 21). 
Table 2: Poder in the Spanish corpus: tenses and frequencies

\begin{tabular}{|l|l|l|l}
\hline Verb & $\begin{array}{l}\text { Presente de } \\
\text { indicativo }\end{array}$ & $\begin{array}{l}\text { Futuro de } \\
\text { indicative }\end{array}$ & $\begin{array}{l}\text { Presente/Imperfecto de } \\
\text { subjuntivo }\end{array}$ \\
\hline Poder (1522) & 43 & 1381 & 98 \\
\hline
\end{tabular}

(20) Si existieran pérdidas de ejercicios anteriores que hicieran que ese valor del patrimonio neto de la Sociedad fuera inferior a la cifra del capital social, el beneficio deberá destinarse en primer lugar a compensar dichas pérdidas, y sólo entonces podrán distribuirse dividendos. (Articles of Association Unión Fenosa)

If there are any losses from previous years that cause the net assets of the company to fall below the book value, then the profits should first and foremost be used to compensate for these losses, and only then can there be dividends. (Articles of Association Unión Fenosa)

(21) Podrá asistir a la Junta General, con voz y sin voto, el Director Gerente. (Articles of Association Ingra)

The director may participate in the meeting, but only in an advisory capacity. (Articles of Association Ingra)

\subsubsection{Translation options}

What are the translation options for these modal verbs and tenses? First of all, we would like to note that the way in which modal verbs and tenses are used in legal documents "is a question of language usage in drafting practices" (Šarčević, 2000, p. 137). And that for that very reason, "legal speech acts cannot be translated literally" (Šarčević, 2000, p. 139). A second observation is related to the ambiguity in the interpretation of the modal verbs and tenses: this is true of Dutch and Spanish, as is evident from our research, but also of English, French and German, according to Šarčević (2000, pp. 136-145). A third observation concerns the high expectations placed on the legal translator and on the interpretation of the source text:

Moreover, it is necessary for translators to determine whether the source provision is mandatory or directory and to formulate a legal norm with the same normative intensity, as it is called. Failure to distinguish between mandatory and directory provisions can have serious repercussions on the application of the legal rule in practice. Mandatory provisions are compulsory and noncompliance is punishable by sanction or may render the instrument or procedure invalid. (Šarčević, 2000, p. 138) 
Our position is more modest: a legal text should primarily be interpreted by a lawyer or judge. The translator does not interpret, unless he or she has no choice. As far as JuriGenT is concerned, our basic premise is that we should explain to the translator that replacing the meaning contained in a grammatical element, such as tense, by an explicit lexical element, represents an interpretation.

\subsubsection{Dutch $>$ Spanish}

The lexical elements in Dutch to express command are dienen te and moeten. These are expressed, in order of frequency, by deber, haber de and tener que in Spanish. On account of the low incidence of tener que compared to the other forms, it is placed between brackets in Table 3 . Dienen te and haber de are more formal than the other forms. The Dutch verbs are mainly used in the indicative present, while the Spanish verbs are more commonly in the futuro de indicativo (see Table 1). Replacing the modal verb by the futuro of the relevant Dutch infinitive is certainly an option, but is less clear-cut.

Kunnen [can] (freedom) and mogen [may] (permission) can only be translated by poder [can, may]. Periphrastic translations such as estar autorizado/tener la autorización [be authorised/have the authority] or tener la capacidad/ser posible o deseable [have the ability/be possible or desirable] are certainly possible, even though they already entail an interpretation which, in our opinion, should be left to the lawyer or judge.

Grammatical elements include the indicative present and the future tense. The indicative present in Dutch is clearly deontic, although there is a fine line between obligation and authority in certain instances. Our translation proposal would be to translate it by the tense with the same use in Spanish, namely the futuro de indicativo. The Spanish presente de indicativo is also a translation option, especially for state verbs: see ex. 22 below. By way of illustration: está(n) representado $(s) / a(s)$ has 15 hits in our corpus, estará(n) representado $(s) / a(s) 22$. In Table 3, we have placed the presente de indicativo between brackets, however, for the reason that its incidence is clearly lower than that of the futuro, especially in nonstate verbs. Verbs expressing commands or authority, such as deber, haber de or poder, represent an interpretation.

(22) Het gedematerialiseerde aandeel wordt vertegenwoordigd door een boeking op rekening op naam van de eigenaar of de houder bij een erkende instelling [...]. (Articles of Association of Exmar) The dematerialised share is represented by an entry in an account in the name of the owner or holder at a recognised institution. (Articles of Association Exmar) 
Las acciones desmaterializadas están/estarán representadas mediante anotaciones en cuenta a nombre del propietario o del poseedor en una entidad reconocida. (My translation)

The dematerialised shares are/ shall be represented by an entry in an account in the name of the owner or holder at a recognised institution. (Articles of Association Exmar)

In the Dutch corpus, the future tense is often temporal, and occasionally deontic. In both cases, the translation by a futuro de indicativo is the recommended route.

Table 3: Translation options Dutch $>$ Spanish for the expression of deontic modality

\begin{tabular}{|c|c|}
\hline Dutch source & Spanish target \\
\hline \multicolumn{2}{|r|}{ LEXICAL } \\
\hline \multicolumn{2}{|r|}{ Command } \\
\hline Moeten (571) & \multirow[t]{2}{*}{ Deber, haber de (formal), (tener que) } \\
\hline Dienen te (159) (formal) & \\
\hline \multicolumn{2}{|r|}{ Authority } \\
\hline Kunnen (1455) & \multirow[t]{2}{*}{ Poder } \\
\hline Mogen (573) & \\
\hline \multicolumn{2}{|r|}{ GRAMMATICAL } \\
\hline \multicolumn{2}{|r|}{ Command/Authority } \\
\hline Indicative present & Futuro de indicativo, (presente de indicativo) \\
\hline Future tense & Futuro de indicativo \\
\hline
\end{tabular}

\subsubsection{Spanish $>$ Dutch}

The three Spanish imperative verbs (deber, haber de (formal), tener que) can be translated by the Dutch equivalents moeten (less formal) and dienen te (formal), which also express a command. Deber de in its radical variant appears five times, but since the RAE \& AALE (2009, vol. II, $\S 28.6 \mathrm{k}$ ) does not recommend this use, we have not included it in our table.

The meanings of poder are those implied in mogen and kunnen. It seems that the translator is forced here to interpret the source text. Accordingly, poder in ex. 20 should be translated as kunnen and in ex. 21 
by mogen. The customary polysemy of both verbs in legal documents (Deschamps, 2010, p. 173) suggests, however, that this is not straightforward. In the table, they are juxtaposed as equivalents.

The Spanish futuro fulfils the same role as the Dutch deontic present and is, therefore, best translated by that tense. This means, inter alia, that the tension between present and future tense in Spanish (Chierichetti, 2001, p. 248, ex. 20) is absent in Dutch. If we are looking to achieve the same outcome in Dutch, then, by way of grammatical compensation, the imperative futuro can be translated by a lexical element. The translation by a future tense is possible in theory, but leads to a less than acceptable style, and is, for that reason, not included in the table.

The Spanish phenomenon where a lexical element is in the futuro, is rare in Dutch: zal dienen te has 4 hits out of 159, two of which have deontic meaning, and zal moeten 1 hit out of 571, with temporal meaning. Only in the latter cases should it be considered to translate the Spanish futuro de indicativo by its homonym.

Table 4: Translation options Spanish $>$ Dutch for the expression of deontic modality

\begin{tabular}{|c|c|}
\hline Spanish source & Dutch target \\
\hline \multicolumn{2}{|c|}{ LEXICAL } \\
\hline \multicolumn{2}{|c|}{ Command } \\
\hline Deber (600) & \multirow[t]{3}{*}{ Moeten, dienen te (formal) } \\
\hline Haber de (257) (formal) & \\
\hline Tener que (7) & \\
\hline \multicolumn{2}{|c|}{ Authority } \\
\hline Poder (1522) & Kunnen, mogen \\
\hline \multicolumn{2}{|c|}{ GRAMMATICAL } \\
\hline \multicolumn{2}{|c|}{ Command/Authority } \\
\hline Presente de indicativo & Indicative present \\
\hline Futuro de indicativo & Indicative present \\
\hline
\end{tabular}

\subsubsection{Terminological processing}

The JuriGenT termbase contains various records on deontic concepts, both on nouns, such as verplichting/obligación, bevoegdheid/facultad, 
and periphrastic expressions, such as verplicht zijn/ser obligatorio... On the basis of the present research, we added two records: one on moeten (Figure 1) and one on kunnen/mogen (Figure 2).

In accordance with the GenTerm practice at Ghent University, each term record starts with an overview, which gives an overarching concept description (in Dutch) and an overview of all the equivalents. However, the term record also contains separate fields (i.e. indexes) for the individual terms and each term also receives a quoted definition where this is available (not visible in the screenshots below).

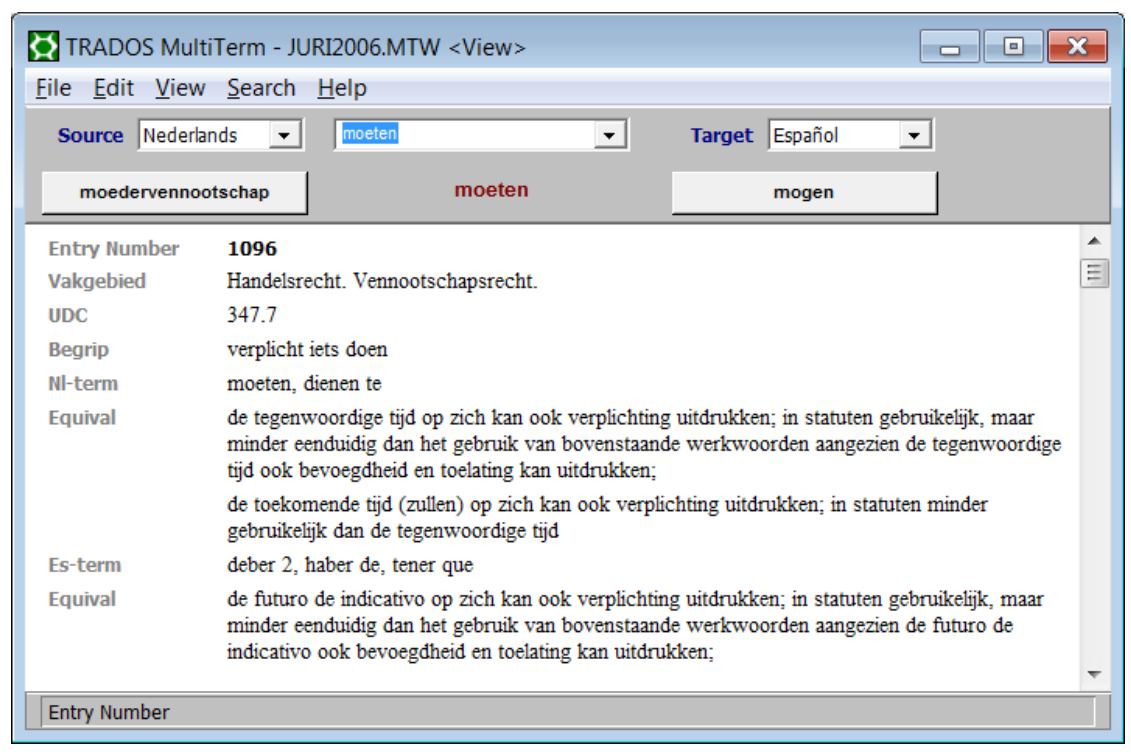

Figure 1: JuriGenT, partial record of the concept moeten 


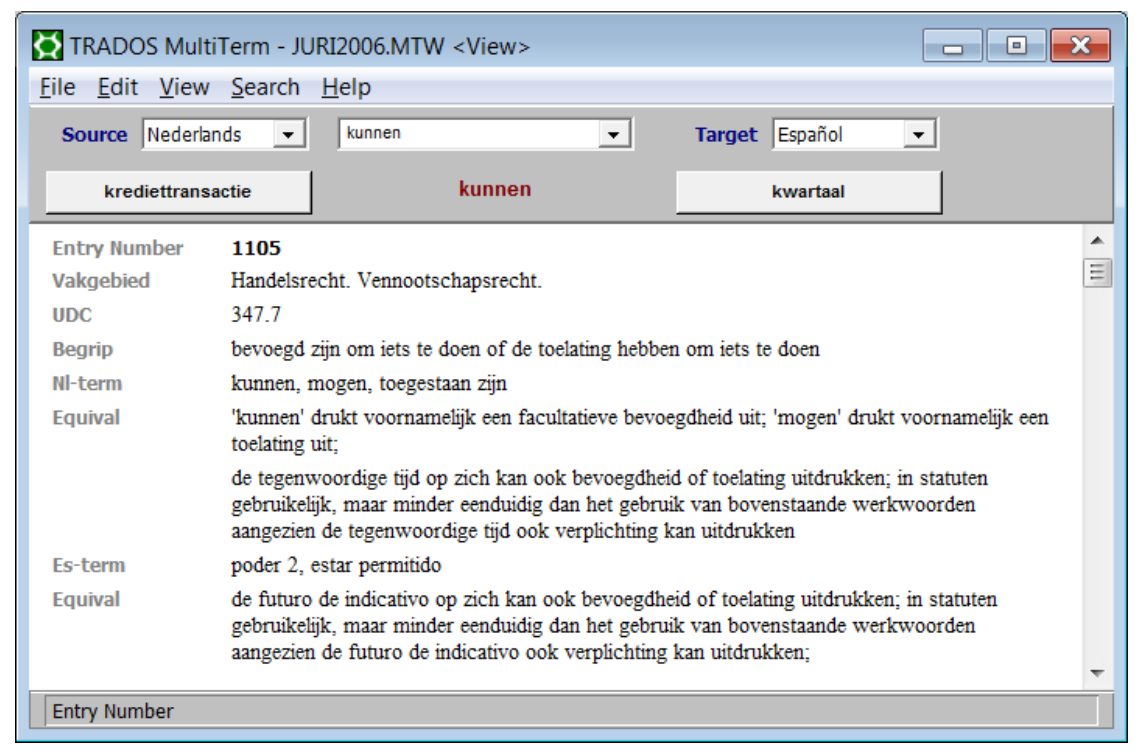

Figure 2: JuriGenT, partial record of the concept kunnen/mogen

The difficulty is in the terminological processing of the use of the tenses as a deontic element per se. Since they cannot be included as terms, we have incorporated the findings concerning the use of the tenses in the 'equivalence' field, without entering into any lengthy detail. It should be clear that while the use of a tense is polysemic in itself, which can lead to confusion, there is an imbalance in the use of the tenses in both languages, and the Dutch indicative present has, in many cases, the same function as the Spanish futuro. The use of the less customary deontic Spanish indicative present and deontic Dutch future tense is mentioned on the general term record, but with the caveat that they are less prevalent.

Other than in the above records, the use of the tenses is only expressed via quoted contexts and sometimes in collocations. For example, the equivalent of the collocation de vennootschap draagt de naam / la sociedad girará bajo la denominación de [the company bears/shall bear the name], whereby draagt is a present and girará a futuro. The same applies to de stem van de voorzitter is doorslaggevend which is expressed with futuro in Spanish: el voto del presidente será dirimente, decidirá el voto del presidente [the vote of the Chairman shall be final]. 


\section{Conclusion}

The aim of this article was to process in terminological terms a discourserelated feature of cross-linguistic variation in the genre of Articles of Association, namely the expression of deontic modality.

The study has clearly demonstrated that (a) both Dutch and Spanish apply lexical and grammatical elements in this connection and (b) in literature on this subject, in both languages, there appears to be consensus surrounding the interpretation of the lexical elements, namely the meaning of the verbs, but that the interpretation of the grammatical elements, namely the meaning of the tense of the verb, is ambiguous and (c) there is, in the main, an imbalance between the two languages with regard to the use of the tenses: Dutch will mainly use an indicative present to convey the deontic concept, while Spanish will favour the futuro de indicativo. On the term records, we processed this main piece of information in a special field which accommodates the conceptual discrepancies between the two legal systems.

Moreover, we gave the translators the opportunity to make conscious translation choices and stipulate clearly that translating grammatical elements that convey deontic modality by lexical equivalents from the other language, already implies concretisation. Admittedly, the translator may still be forced to interpret, precisely because of the existing inconsistency: more particularly in the case of the translation of poder.

The approach described in the legal termbase JuriGenT seeks to offer the legal translator insights into the complexities of legal translation. The discourse-related aspects discussed in this paper are just a first step. Other aspects that merit contrastive research in due course include: the way reference is made to laws, the doublets and triplets, and the lists of synonyms and quasi synonyms (Bhatia, 1994, p. 144).

\section{References}

Alcaraz, E., \& Hughes, B. (2002). Legal translation explained. Manchester: St. Jerome.

Álvarez Calleja, M. A. (2002). Traducción jurídica inglés-español. Madrid: Librería UNED.

Bhatia, V. K. (1994). Cognitive structuring in legislative provisions. In J. P. Gibbons (Ed.), Language and the law (pp. 136-155). London: Longman.

Biel, Ł. (2009). Organisation of background kwowledge structures in legal language and related translation problems. Comparative legilinguistics: International Journal for Legal Communication 1, 176-189. http://ug.academia.edu/LucjaBiel/Papers/329480s [consulted 11.09.2012]

Biel, Ł. (2010). Corpus-based studies of legal language for translation purposes: Methodological and practical potential. In C. Heine \& J. Engberg (Eds.), 
Reconceptualizing LSP. Aarhus: Online proceedings of the XVII European LSP Symposium 2009.

http://www.asb.dk/fileadmin/www.asb.dk/isek/biel.pdf [consulted 29.10.2012]

Borja Albi, A. (2007). Estrategias, materiales y recursos para la traducción jurídica inglés-español. Madrid: Edelsa, Grupo Didascalia.

Borja Albi, A., \& Hurtado Albir, A. (1999). La traducción jurídica. In A. Hurtado Albir (Ed.), Enseñar a traducir (pp. 154-160). Madrid: Edelsa, Grupo Didascalia.

Cabré, M. T., Estopà, R., Freixa, J., Lorente, M., Martí, J., \& Tebé, C. (2003). La enseñanza de la terminología en la traducción especializada: nuevas propuestas para viejos problemas. In N. Gallardo San Salvador (Ed.), Terminología y traducción: Un bosquejo de su evolución (pp. 117-129). Granada: Atrio.

http://www.upf.edu/pdi/iula/merce.lorente/docums/comunic1.pdf (consulted 12.11.2012)

Cabré Castellví, M. T. (2005). ¿Necesita un traductor saber y saber hacer terminología? Invited talk for the Karel V-Leerstoel. Universiteit Gent, Hogeschool Gent, 24 March.

Chierichetti, L. (2001). La modalidad deóntica en el Código Civil español: Apuntes para una comparación con el Codice Civile italiano. In M. Gotti \& M. Dossena (Eds.), Modality in specialized texts (pp. 239-259). Bern: Peter Lang.

Croft, W. (1995). Modern syntactic typology. In M. Shibatani \& T. Bynon (Eds.) Approaches to language typology: Past and present (pp. 85-143). Oxford: Oxford University Press.

Deschamps, K. (2010). Standaardisering van deontische uitdrukkingsmiddelen in regelgevende teksten. In E. Hendrickx, K. Hendrickx, W. Martin, H. Smessaert, W. Van Belle, \& J. van der Horst. (Eds.), Liever meer of juist minder?: Over normen en variatie in taal (pp. 165-179). Ghent: Academia.

Deschamps, K., \& Smessaert, H. (2011). (Non-)modal uses of the present indicative in Dutch legislation. Cahiers Chronos, 22, Chronos edition, 7, 139-156.

Evans, V. (2006). Lexical concepts, cognitive models and meaning construction. Cognitive Linguistics, 17(4), 491-534.

Gémar, J.-C. (2002). Le plus et le moins-disant culturel du texte juridique : Langue, culture et équivalence. Meta. Translators' Journal, 47(2), 163-176.

Hildebrandt, M., \&. Gaakeer A. M. P. (2005). Wetenschap in rechte. The Hague: Boom.

Kierzkowska, D. (Ed.). (2005). Kodeks ttumacza przysięgtego z komentarzem. Warsaw: Tepis.

López Samaniego, A. (2006). El uso metaargumentativo de las perífrasis obligativas en el lenguaje jurídico español. In M. V. Calvi \& L. Chierichetti (Eds.), Nuevas tendencias en el discurso de especialidad (pp. 117-140). Bern: Peter Lang.

López Samaniego, A., \& Taranilla, R. (2012). Análisis contrastivo de la formulación de recomendaciones en dos géneros jurídicos. Ibérica 23. http://www.aelfe.org/documents/04_23_Lopez.pdf (consulted 12.11.2012) 
Mayoral Asensio, R. (2003). Translating official documents. Manchester: St. Jerome.

Nord, C. (1997). Translating as a purposeful activity: Functionalist approaches explained. Manchester: St. Jerome.

Ortega Arjonilla, E., Doblas Navarro, M. del C., \& Paneque Arana, S. (1996). Peculiaridades del lenguaje jurídico desde una perspectiva lingüística. In P. San Ginés Aguilar \& E. Ortega Arjonilla (Eds.), Introducción a la traducción jurídica y jurada (inglés-español) (pp. 25-38). Granada: Editorial Comares,

Palmer, F. R. (2001). Mood and modality. Cambridge: Cambridge University Press.

Real Academia Española (RAE) (1973). Esbozo de una nueva gramática de la lengua española. Madrid: Espasa-Calpe.

Real Academia Española \& Asociación de Academias de la Lengua Española (RAE \& AALE) (2009). Nueva gramática de la lengua española. Madrid: Espasa Libros.

Šarčević, S. (2000). New approach to legal translation. The Hague: Kluwer.

Stubbs, M. (2004). Language corpora. In A. Davies \& C. Elder (Eds.),Handbook of applied linguistics (pp. 106-132). Oxford: Blackwell.

Taranilla, R. (2010). Forma y función de los enunciados jurídicos de recomendación: Las recomendaciones de la Comisión Europea. In L. Chierichetti \& G. Garofalo (Eds.), Lengua y derecho: Líneas de investigación interdisciplinaria (pp. 249-272). Bern: Peter Lang,

Temmerman, R. (2000). Towards new ways of terminology description: The sociocognitive approach. Amsterdam: John Benjamins.

Teubert, W. (2002). The role of parallel corpora in translation and multilingual lexicography. In B. Atenberg \& S. Granger (Eds.), Lexis in contrast (pp. 189214). Amsterdam: John Benjamins.

Vanden Bulcke, P., \& Héroguel, A. (2011). Quality issues in the field of legal translation. In I. Depraetere (Ed.), Perspectives on translation quality (pp. 211-249). Berlin: De Gruyter.

Vanden Bulcke, P., \& De Groote, C. (2011). La base de datos terminológica jurídica bilingüe diseñada para el traductor: $\mathrm{O}$ sobre la necesidad de la inclusión de más unidades terminológicas y fraseológicas y de unidades de enlace. In ITL. A special issue on LSP, 162, 84-110. 